\title{
The ominous side of a coronary fistula
}

\author{
Glória Abreu, ${ }^{1}$ Pedro Azevedo, ${ }^{1}$ Jorge Marques, ${ }^{1}$ Sérgio Nabais ${ }^{2}$
}

${ }^{1}$ Department of Cardiology, Hospital de Braga, Braga, Portugal

${ }^{2}$ Department of Cardiology, Salisbury NHS Foundation Trust, Salisbury, UK

\section{Correspondence to}

Dr Gloria Abreu, gloriappabreu@gmail.com

This clinical case was presented and selected as finalist for the "Case-based session Club 35" Award Competition at EuroEcho Imaging 2014, Vienna, Austria

Accepted 7 August 2015

To cite: Abreu $\mathrm{G}$, Azevedo P, Marques J, et al. BMJ Case Rep Published online: [please include Day Month Year] doi:10.1136/ bcr-2015-212158

\section{DESCRIPTION}

Coronary artery fistulas are rare and estimated to occur in $0.002 \%$ of the overall population. ${ }^{1}$ Most patients remain asymptomatic, but angina, dyspnoea, arrhythmias or sudden death may arise. ${ }^{2}$

We report the case of a 65 -year-old man with previous hypertension, angina and obesity, who presented to accident and emergency department with oppressive central chest pain initiated whilst driving. During initial observation he had a cardiac arrest in ventricular fibrillation, which was promptly treated. His cardiovascular physical examination did not show any abnormal signs. The 12 lead ECG showed sinus rhythm, Q waves in III
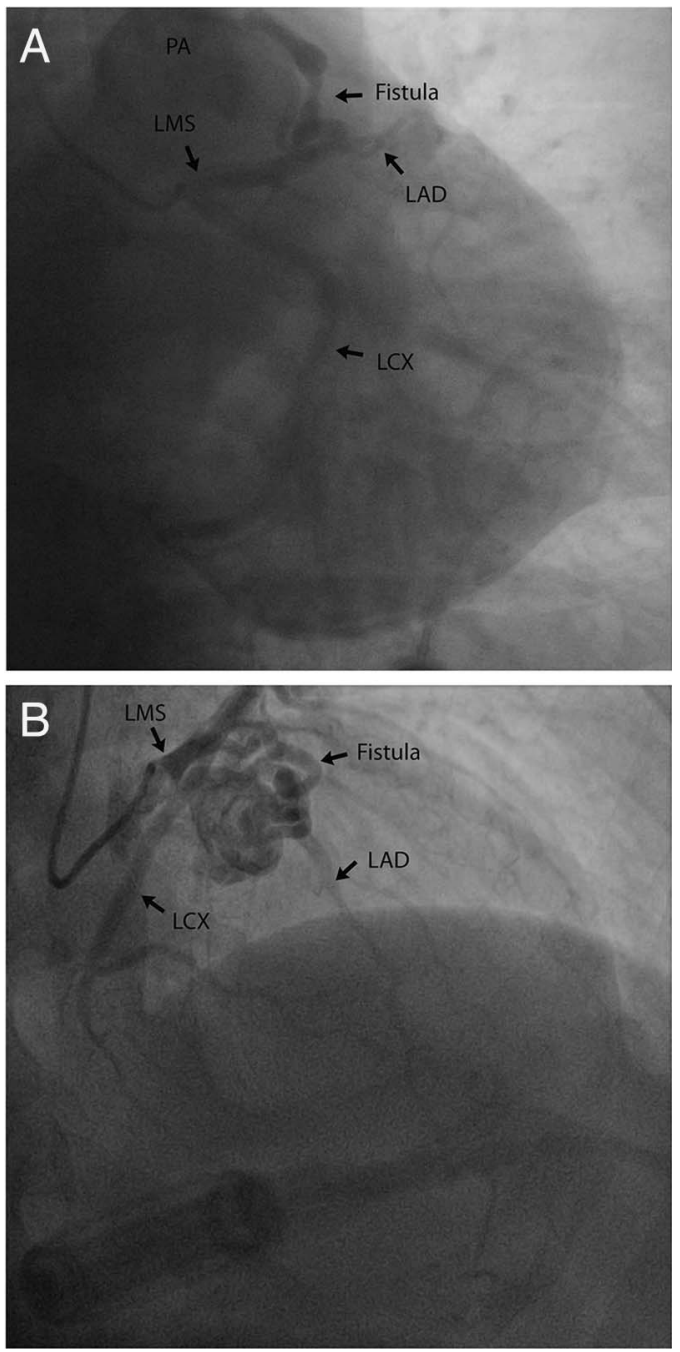

Figure 1 Selective angiography of the left coronary artery ((A) $45^{\circ} \mathrm{LAO}, 25^{\circ}$ cranial view; (B) $10^{\circ} \mathrm{RAO}, 40^{\circ}$ cranial view), showing a large fistula from the very initial portion of the LAD artery to PA, and atrophy of mid and distal segments of the $L A D$ artery (LAD, left anterior descending; LCX, left circumflex artery; LMS, left main stem; PA, pulmonary artery).

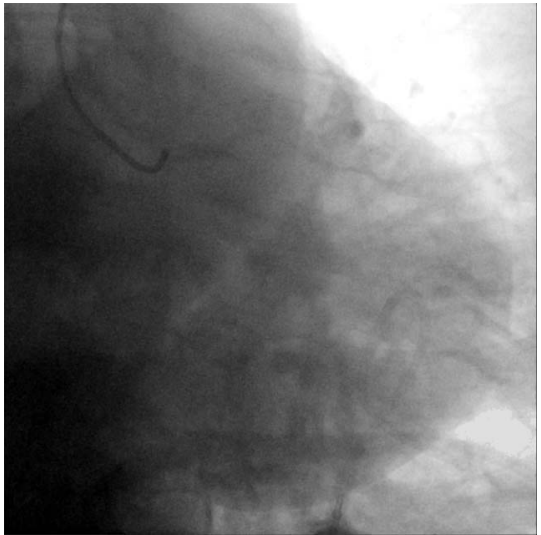

Video 1 Coronary angiography showing no atherosclerotic stenosis, but a large tortuous fistula between proximal segment of left anterior descending coronary artery and pulmonary artery.

and aVF, and T-wave inversion in $\mathrm{I}, \mathrm{aVL}$ and $\mathrm{V} 4$ V6 leads. Blood tests revealed mild raised troponin I $(4.2 \mathrm{ng} / \mathrm{mL})$. Mild left ventricle dilation and apical hypokinesis were observed in the transthoracic echocardiogram. The patient was referred for an urgent coronary angiogram, which showed a large fistula between the very proximal segment of the left anterior descending artery and the pulmonary artery, with no significant coronary artery stenosis (figure 1 and video 1). A CT coronary angiogram confirmed this congenital tortuous vascular anomaly measuring $5 \mathrm{~mm}$ in diameter and $7 \mathrm{~cm}$ in length (figure 2). Cardiac MRI did not depict any
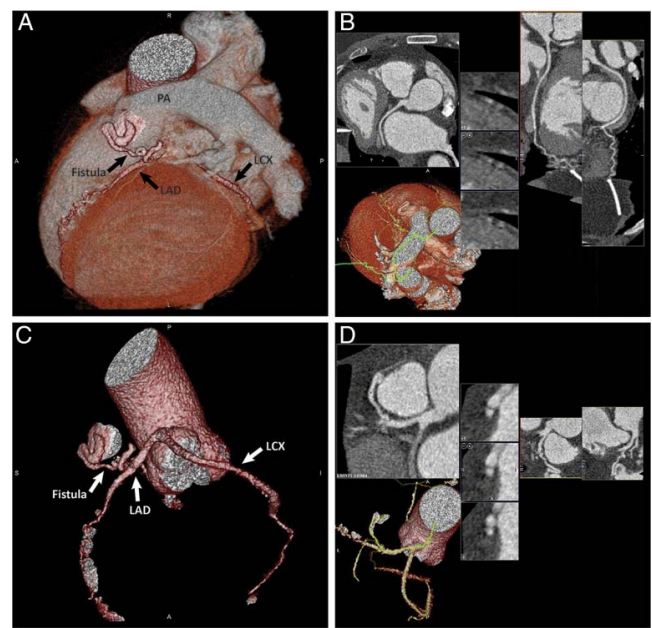

Figure 2 Coronary CT angiogram (A-D) confirming a congenital tortuous vascular anomaly between the proximal $L A D$ artery and ascendant portion of the $P A$, and atrophy of mid and distal segments of the LAD artery ( $L A D$, left anterior descending; $L C X$, left circumflex artery; PA, pulmonary artery). 
areas of scar, late enhancement or oedema. Considering the clinical context and the size of the fistula, with no other obvious reason for the cardiac arrest, the symptoms were felt to be the result of a steal phenomenon and the patient was submitted to percutaneous closure of the fistula.

This case demonstrated how some coronary fistulas are not benign conditions and can present with myocardial ischaemia and malignant arrhythmias.
Contributors GA collected the data and wrote the manuscript. SN performed the catheterisation. All the authors were involved in this clinical case and contributed to the conception of the work, reviewed the manuscript for important intellectual content and gave final approval of this article.

Competing interests None declared.

Patient consent Obtained.

Provenance and peer review Not commissioned; externally peer reviewed.

\section{Learning points}

- This case shows that the first serious manifestation of a coronary artery fistula can be a life-threatening arrhythmia.

- Despite being rare, this entity should be considered when dealing with patients who experience angina or sudden cardiac arrest.

- It is commonly accepted that symptomatic patients and those who have large fistulas should be treated. ${ }^{3}$

\section{REFERENCES}

1 Dodge-Khatami A, Mavrousdis C, Baker CL. Congenital Heart Surgery Nomenclature and database Project: anomalies of coronary arteries. Ann Thorac Surg 2000;69:270-97.

2 Harle T, Kronberg K, Elsasser A. Coronary artery fistula with myocardial infarction due to steal syndrome. Clin Res Cardiol 2012;101:313-5.

3 Auf der Maur C, Chatterjee T, Erne P. Percutaneous transcatheter closure of coronary-pulmonary artery fistula using polytetrafluoroethylene-covered graft stents. J Invasive Cardiol 2004;16:386-8.

Copyright 2015 BMJ Publishing Group. All rights reserved. For permission to reuse any of this content visit http://group.bmj.com/group/rights-licensing/permissions.

BMJ Case Report Fellows may re-use this article for personal use and teaching without any further permission.

Become a Fellow of BMJ Case Reports today and you can:

- Submit as many cases as you like

- Enjoy fast sympathetic peer review and rapid publication of accepted articles

- Access all the published articles

- Re-use any of the published material for personal use and teaching without further permission

For information on Institutional Fellowships contact consortiasales@bmjgroup.com

Visit casereports.bmj.com for more articles like this and to become a Fellow 